\title{
成羽層群の炭層地すべり群 一岩相と地史を反映したその構造特性*
}

Coaly beds landslides of the Triassic Nariwa Group

- Characteristics of landslide structures influenced by their lithofacies and geohistory

\author{
横田修一郎 ${ }^{1}$ 田中 元 $^{2}$ \\ 山田环哉 ${ }^{2}$
Shuichiro Yokota ${ }^{1}$, Hajime Tanaka ${ }^{2}$ and Takuya Yamada ${ }^{2}$

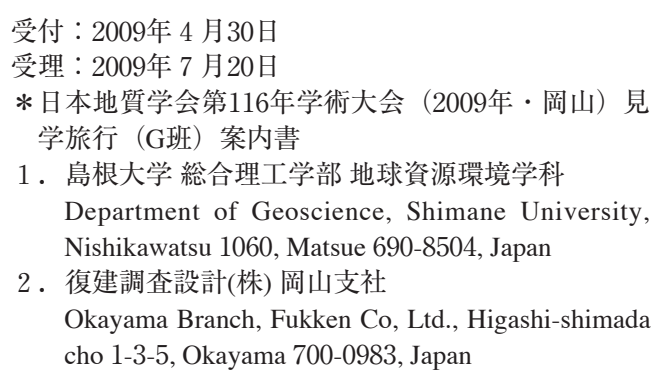 \\ Corresponding author: S.Yokota \\ E-mail: yokota@ riko.shimane-u.ac.jp
}

\begin{abstract}
概 要
地すべりは, 斜面崩壊や落石, 土石流などに比較して突発的な災害を発 生させることは少ないものの，大小様々な地すべりによる被害は今日でも 後を絶たない，岡山県西部に分布する上部トリアス系成翏層群の分布域は 地すべり多発地带であり，農地や家屋等の被害に対して調査と対策が繰り 返されてきた。これらの地すべりは“成羽層群地すべり”とよばれ，成羽 層群の砂岩・泥岩中に挟まれる薄い炭層や特有の小褶曲構造がその発生に 関与していると考えられている，本見学コースでは当地域のこうした地す ベりの形態と構造の特徵をとらえ，発生にかかわる地形・地質条件を地質 学あるいは応用地質学の立場から考えることを目的とする.
\end{abstract}

\section{Keywords}

地すべり，成羽層群，炭層，褶曲

landslides, Nariwa Group, coaly beds, folds

地形図

$1: 25,000$ 「地頭」

\section{見学コース}

$8: 30$ 岡山駅西口出発 $\rightarrow$ 岡山県高梁市川上町（名原 $\rightarrow$ 大賀 $\rightarrow$ 松原 $\rightarrow$ 仁賀 $\rightarrow$ 安成 $\rightarrow$ 地頭） $\rightarrow 18: 00$ 岡山駅西口解散

\author{
見学地点

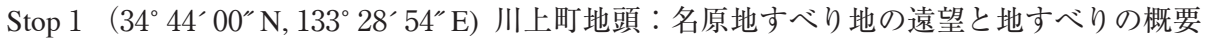

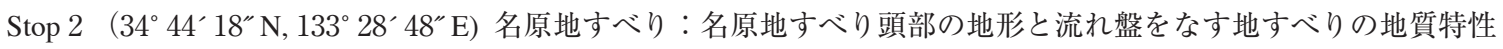

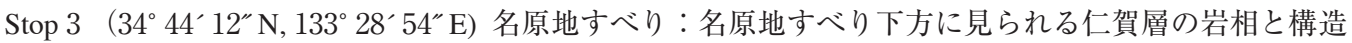

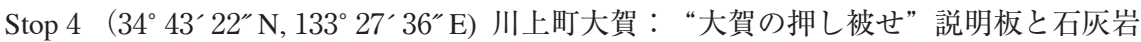

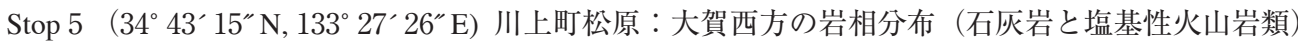 \\ Stop 6 (34 $\left.44^{\circ} 42^{\prime \prime} \mathrm{N}, 133^{\circ} 27^{\prime} 30^{\prime \prime} \mathrm{E}\right)$ 仁賀地区高原上：山砂利層と吉備高原

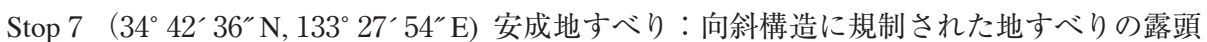

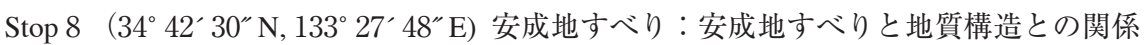 \\ Stop 9 (34 $\left.42^{\circ} 48^{\prime \prime} \mathrm{N}, 133^{\circ} 27^{\prime} 42^{\prime \prime} \mathrm{E}\right)$ 安成地区高原上：山砂利層直下の風化した成羽層群

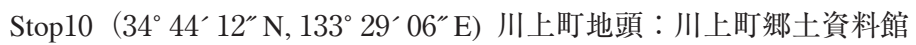


はじめに

地すべりは，斜面崩壊や落石，土石流などに比較して突発 的な災害を発生させることは少ないものの, 大小様々な地す べりによる被害は今日でも後を絶たない. 岡山県西部に分布 する上部トリアス系成羽層群の分布域（第 1 図）は地すべり 多発地帯であり, 農地や家屋などの被害に対して調査と対策 が繰り返されてきた。これらの地すべりは“成羽層群地すべ り”とよばれ, 成羽層群の砂岩・泥岩中に挟まれる薄い炭層 や特有の小褶曲構造がその発生に関与していると考えられて いる（田中ほか，2006，2007）. 本見学コースでは, 当地域 のこうした地すべりの形態と構造の特徴をとらえ, 発生にか かわる地形・地質条件を地質学あるいは応用地質学の立場か ら考えることを目的とする．

成羽層群は炭層を含むことから地質研究の歴史は古い.し かし, 多数の小規模な褶曲構造に上記のような地すべり移動 による表層の構造が加わっていることから, 地質構造は複雑 であり, 全貌の解明は長い間困難であった。 とくに, 大賀地 区では地質構造が複雑で, 石炭紀〜ペルム紀化石を含む石灰 岩が見かけ上トリアス系砂岩の上位に現れることから，“大 賀デッケ (大賀の押し被せ)”とよばれるナップ構造が指摘 されたこと（小澤, 1924; Ozawa, 1925）はよく知られている.

成羽層群の地質構造解明はその後しだいに進み, “大賀デ ッケ”に関しても様々な解釈が可能となってきた（沖村・長 谷, 1973 ; 大藤, 1985 ; 鈴木ほか, 1990など). さらに, 地す ベり移動に起因した表層の構造も部分的に明らかになり, 基 盤の構造と併せた議論も可能になりつつある（横田ほか, 1998).

本見学コースではこうした研究を踏まえ, 成羽層群地すべ
りの代表として高梁市川上町の亮原地すべりと安成地すべり をとりあげ，地すべり発生にかかわる成羽層群の岩相，とく に頻繁に挟まれる脆弱化した炭層の役割や特徵的な小褶曲構 造などを見学する.さらに, 当地域の地史を考えるうえで重 要な古第三系の碟層 (山砂利層) の層相と分布を見学し, そ れが示す地域の風化環境を通じて地すべり発生との関係も考 えてみる。

\section{高梁市川上地域の地形・地質概要}

見学地域は第 1 図(a)に示すように, 岡山県中部の高梁市市 街地の南西10〜 $15 \mathrm{~km}$ の川上町地頭, 大賀, 安成, 仁賀など を含めた範囲である. 広域的には, 吉備高原とよばれる標高 300〜 400mの定高性をもった山地が広がり, 瀬戸内海に注ぐ 高梁川水系の成羽川，領家川などがそれを開析している. 吉 備高原の中でも成羽層群分布地域は地形的にやや低く, 盆地 状を呈しているが，この地形的低まりは成羽層群とその基盤 岩類との間で生じた一種の組織地形と考えられる. 山腹には 地すべり性緩斜面が各所に見られ，それらの多くは耕作地と して利用されている.

当地域の成羽層群は砂岩, 泥岩とそれらの互層を主体と し，砂岩は部分的に碟岩を含んでいる．本層群から産出する Entomonotisや植物化石は古くから研究され（例えば，大石， 1931; 小林ほか，1937），それらに基づいて地質時代はトリア ス紀後期Norianとされている. 小林ほか（1937）は産出化石 と岩相から, 本層群を碩岩に富んだ下部層, 砂岩・泥岩主体 の中部層, 砂岩に富みEntomonotisを産する上部層の 3 層に区 分した. また, 寺岡 (1959) は下位より, 最上山層, 日名畑 層, 地頭層とよんだ。しかし, 岩相の単調さと側方変化の著 しさとともに層理面の走向・傾斜が頻繁に変化することか

(a)

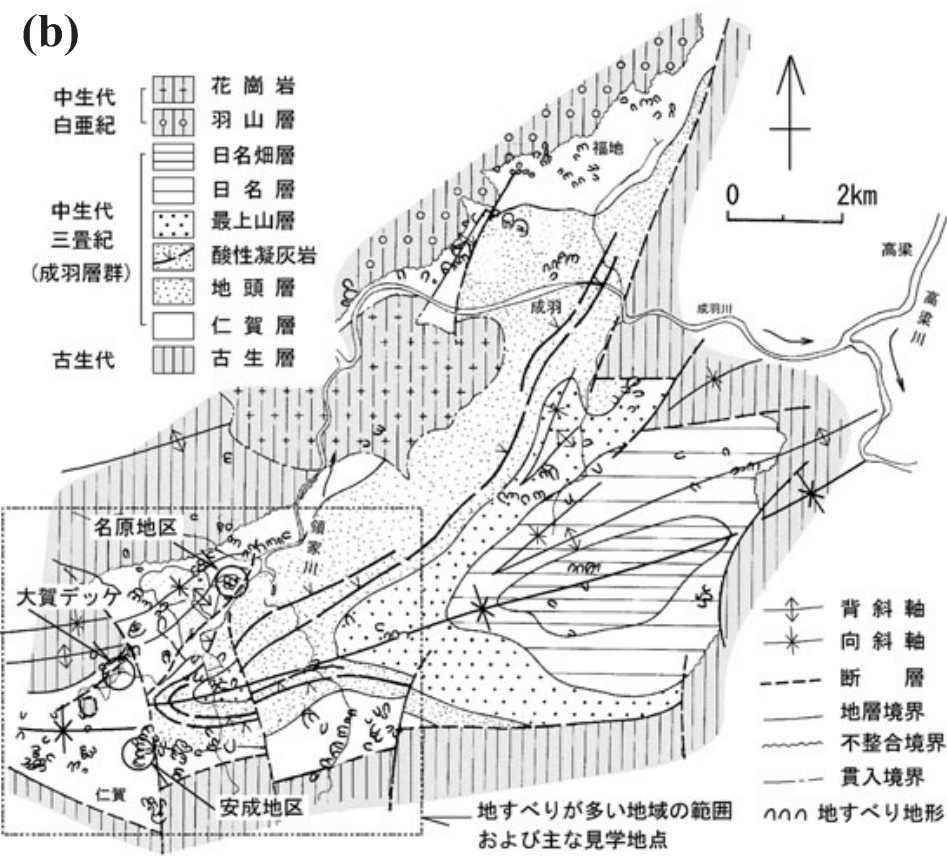

第 1 図 見学地域の地質概要. (a) 成羽層群分布地域周辺の地形概要（田中ほか, 2006). (b) 高梁市成羽地区〜川上地区の成羽層群を主体 とした地質図 (鈴木・Asiediu，1995に加筆) 
ら，詳細な層序や全体の構造は長い間不明であった。

1980年代になって，大藤（1985），鈴木ほか（1990）は砂 岩・泥岩に挟まれている酸性凝灰岩薄層を鍵層として構造の 把握に努め, 成羽層群は大局的にはENE-WSW走向で鉛直に 近い褶曲軸面をもつ向斜構造が基本であるとした。さらに， 鈴木・Asiedu（1995）はこうした地質構造をなす成羽層群を， 下位から仁賀層, 地頭層, 最上山層, 日名層, 日名畑層の 5 層に細分した（第 1 図(b)）。このうち，地頭層のみが海成で あり, 他は河川成の陸成層と考えられている. 後者には上方 細粒化のユニットがいくつか認められ, 薄い炭層が頻繁に挟 まれているのが特徵である.

成羽層群分布域の周辺には, 石灰岩や砂岩・粘板岩を主体 として成羽層群の基盤をなす非変成ペルム系, 凝灰岩や凝灰 質砂岩を主体として成羽層群を覆う白亜紀前期の硯石層（関 門層群相当層), さらに白亜紀後期の火砕岩類や花崗岩類な どが分布している。一方，吉備高原の一部をなす定高性をも った山稜部には “山砂利層”とよばれる鿬層が点在してお り, 古第三紀の河川成堆積物と考えられている（松浦ほか, 2002 ; 鈴木ほか, 2003 ; 田中ほか, 2003; Tanaka and Suzuki, 2004など).

\section{成羽層群地すべりの概要}

成羽層群の分布域は岡山県下でも有数の地すべり地帯であ り, 緩斜面を伴った地すべり地形が多数点在しているととも に, 地すべり防止区域や同危険箇所が密集している（田中ほ か, 2006). 今回見学する名原地すべりなどの多くの地区で は, 昭和40年代を中心として地すべり変動が活発化し, 農地 や家屋が被災した。

第 1 図(b)は成羽層群の岩相層序区分上に地すべり地形の 分布を示したものである. 地すべり地形は, 成羽層群最下位 の仁賀層が広範囲に現れる南西部に多く, 長さ $75 \sim 175 \mathrm{~m}$, 幅 $50 \sim 150 \mathrm{~m}$, 地表面の傾斜15〜22 のものが多い（田中, 2007). こうした成羽層群地すべりの地質素因に関係して 2 つの特徵 が指摘されている（岡本・田中，1990; 田中，1999; 田中ほ か, 2006,2007など). 1 つは脆弱な炭層の存在であり, もう ひとつは小褶曲構造の存在である。前者に関しては, 炭層を 頻繁に含んだ仁賀層分布域で地すべりが密集しており, 炭層 に沿ってすべり面が確認される例が多いこと, 後者に関して は, 地すべりが福地地区, 名原地区などのように背斜構造翼 部の流れ盤に形成されている例や，安成地区のようにプラン ジした向斜構造部軸部に形成されている例（岡本・田中， 1990 ；田中ほか，2006, 2007）のあることがあげられる.

\section{地すべりの地質素因としての成羽層群中の炭層}

成羽層群仁賀層の分布域を中心に，かつては炭層を対象と した炭鉱が多数存在し, 全体は “成羽炭田”とよばれてきた (徳永ほか, 1973). 昭和20年代には練炭や石灰製造用燃料と して数ヶ所で採炭されていたが（河合，1951）, 日の丸炭鉱 の閉山（昭和39年）を最後に皆無となった（川上町岩石植物 調査会, 1970).

河合（1951）に基づけば，当地域の炭層の特徵は，(1)無煙
炭の微粉炭を主とした灰分の多い暗炭であり，油脂感がある こと，(2)薄層で膨縮性に富み，採炭対象の豊肥部（厚さ数〜 10 数m）が褶曲構造の急傾斜から緩傾斜に移る部分に多いこ とが指摘されている，後者は炭層の層厚が褶曲変形に規制さ れた可能性を示している．また，鈴木・小田（1995）に基つ けば，ビトリナイト反射率の変化から，当地域の炭層は白亜 紀花崗岩体の熱的影響を受けており，岩体近傍から外側へ向 かって変無煙炭から無煙炭へと変化する.

炭層中の粘土鉱物に関しては, 井上ほか（2001）が野田地 区の集水井とボーリング試料で，宝谷ほか（1997）が名原地 区のボーリング試料で，さらに田中（2007）が安成地区の露 頭試料で，それぞれすべり面と非すべり面の微粉炭状の炭層 に対するX線粉末回析を行っている。これらによれば，炭層 中の粘土鉱物はイライトが主体で, 含有量はすべり面, 非す べり面のいずれでも $20 \%$ 前後であり，大差はない（田中， 2007).

\section{見学地点}

今回の見学旅行では名原地すべりと安成地すべりを主な対 象とするが，それとともに成羽層群の代表的な岩相，構造， 基盤の石灰岩などとの関係, 緩やかな山稜部に点在する古第 三紀山砂利層なども見学する．見学ルートと各見学地点Stop 1 〜 10 見学地点位置図に示すとともに, 各地点の内容を以 下に記す. Stop 1 〜 9 では地すべりに関連した地形・地質状 態などを，またStop10では当地域の化石・鉱物などを展示し た資料館の見学を予定している.

\section{Stop 1 名原地区地すべり地の遠望と地すべりの概要（高梁 市川上町地頭 ; 第 2 図)}

[地形図] $1: 25,000$ 「地頭」

[位 置] $34^{\circ} 44^{\prime} 00^{\prime \prime} \mathrm{N}, 133^{\circ} 28^{\prime} 54^{\prime \prime} \mathrm{E}$

[解 説] Stop 1 からは, 北西方に緩斜面をなす名原地区地 すべり地の全体を遠望できる．名原地区は古くからの変動経 緯があり，代表的な成羽層群地すべりの 1 つである，領家川 に面した南東向き緩斜面の中に典型的な地すべり地形がいく つか認められる。川上町の市街地背後に位置し，地すべり末 端部を中心に人家が多い。岡山県（2000）によれば，当地区 では後述のAブロックを中心として昭和 36 年，同 $43 \sim 44$ 年， 同47年の豪雨時に活発に変動した。家屋の傾斜，宅地や畑の 亀裂や段差などの変状が現れ，いくつかの民家が移転した。

第 2 図(a)に示すように，地形的には 5 つの地すべりブロッ ク A〜Eが識別される. Aブロックでは, 上部は傾斜 $10 〜 15$ の緩斜面を，下部は約 $35^{\circ}$ の急斜面をなしている。標高約 $200 \mathrm{~m}$, 約 $220 \mathrm{~m}$ に 2 段の滑落崖が認められ，それらによって AブロックはA-1ブロックとA-2ブロックに 2 分される．第 2 四(b)に示すように, 前者は小さくて浅く，その末端は急斜 面中腹の標高 $160 \mathrm{~m}$ 付近にある。これに対して後者は前者を 内包したかたちで大きくて深く，末端は標高 $140 \mathrm{~m}$ 付近の段 丘面へ至っている. 


\section{Stop 2 名原地区地すべり頭部の地形と流れ盤をなす地すべ りの地質特性（高梁市川上町名原；第 2 図）}

[地形図] $1: 25,000$ 「地頭」

[位 置] $34^{\circ} 44^{\prime} 18^{\prime \prime} \mathrm{N}, 133^{\circ} 28^{\prime} 48^{\prime \prime} \mathrm{E}$

[解 説] 名原地区Aブロックの頭部に認められる特徴的地 形と地すべりにかかわる成羽層群の特徴的な岩相である“脆 弱な炭層を繰り返し挟む地層”を中心に，以下の(1)～(5)を見 学する(第 2 図(a)).

(1)A-1，2ブロック頭部の 2 段の滑落崖.

(2)Aブロック地表部を構成する海成の地頭層（Jss層）の風 化砂岩.

(3) Aブロック北側の露天掘り炭鉱跡地. 河川成の仁賀層 (Na1層) 最上部の炭層が採掘対象.

(4)大きく変動した昭和 45 年頃の変状跡地と当時設置された アナログ伸縮計 (一部).

(5)地すべり対策工（第 1 次の排水ボーリング工と第 2 次の 集水井工).

当地区は昭和37年に地すべり防止区域に指定され（岡山県 下で 5 番目), 昭和 36 年から同50年にかけて排水ボーリング 工と表面排水工が広範囲に施工された。これらによって, 全 体の地すべり変動はほぼ沈静化したが, A-1ブロックでは緩 傾斜という地形的制約によって排水ボーリング工が十分配置 できなかったことから，その後も微弱な変動が残っていた。 このため, 平成 4 年から 3 基の集水井工を主体とした対策工 が実施され，同 8 年に概成した。変動はその後現れていな い.

Aブロックには以下の特徴がある. (1)すべり面は粘土状〜 砂状を呈し, 著しく破砕された炭層部に推定される。ブロッ クの構成岩盤は開口亀裂が発達し, 緩んでいる. (2)A-1ブロ ックはA-2ブロックより破砕が進み, 崩積土状となった部分 が多い. (3)地下水位は上下それぞれのすべり面の直上に 2 層 認められ, A-2ブロック頭部付近では地下水位が高く, 地表 付近にある。

第 2 図(b)の地質断面図はボーリングなどに基づいて作成 したものである.深部は仁賀層の夾炭砂岩と泥岩, また浅部 は地頭層の砂岩主体層よりなる，前者は河川成で，Aブロッ ク周辺の沢沿いなどに分布し, 砂岩層, 砂岩・泥岩互層, 泥 岩層，炭層の順で重なる厚さ $5 \sim 10 \mathrm{~m}$ の小規模な上方細粒化 ユニットを構成している，これに対して後者は海成で, 領家 川沿いとAブロックおよびその西側の尾根上に分布し, 地す ベりブロックの最上部を薄く覆うのみである（第 2 図(b)）. したがって，すべり面の多くは仁賀層中にある.

名原地区とその周辺でも, 成羽層群には波長 $400 \mathrm{~m} \sim 1000 \mathrm{~m}$ の褶曲構造が顕著である. 各地すべりブロックは主要な背斜 構造南翼の流れ盤部分に形成されている.すべり面は, 地表 面の傾斜に近い約 $15^{\circ}$ の層理面に沿っていると推定される (第 2 図(b)).

第 2 図(c)はボーリング・コアに基づいた岩相柱状図とコア 形状区分，およびすべり面の位置を示したものである，上位 の地頭層は塊状の中粒砂岩を主体とするが, 地すべり移動に よって崩積土化している. 下位の仁賀層は硬質な砂岩中に泥
岩と軟質化した炭層を頻繁に含んでいる．ボーリング・コア の仁賀層は, 次の特徽からU-1 U-4の 4 つの上方細粒化ユニ ットに区分される. 各ユニット最下部は厚さ $1 \sim 4 \mathrm{~m}$ の砂岩 層, 最上部は炭層を伴う泥岩層からなる。 また, 層厚は変化 するものの, ユニットとしてはほぼ連続し, とくにU-3とU4ユニット下部の砂岩層は鍵層として追跡可能である.

炭層部の細礫化は, 地すべり移動による直接的な影響が少 ない深部（B-4の深度 $9 \mathrm{~m}$ 以深）でも見られることから, 炭 層の脆弱化は地すべり発生前に生じたものと考えられる. 図 中には推定すべり面A-1, A-2を矢印で示しているが, 約 3 年 間の孔内傾斜計観測でA-2すべり面には断続的に $1 \sim 2 \mathrm{~mm}$ の 変位が認められた。

\section{Stop 3 名原地区地すべり下方に見られる仁賀層の岩相と構 造（高梁市川上町名原）}

[地形図] $1: 25,000$ 「地頭」

[位 置] $34^{\circ} 44^{\prime} 12^{\prime \prime} \mathrm{N}, 133^{\circ} 28^{\prime} 54^{\prime \prime} \mathrm{E}$

[解 説] 名原地区下方の領家川沿いでは仁賀層の一部が露 出している（第 2 図(a)）。道路沿いに露出した泥岩優勢の砂 岩・泥岩互層は走向・傾斜の若干の乱れを伴いながら, 全体 として南東へ緩く傾斜している.この下位の部分が領家川河 床に露出しているが，ここでは砂岩優勢層である。これらも

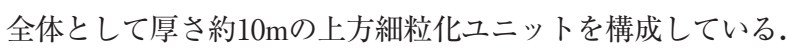
このすぐ上位（南東側）は法面保護工のため現在は見られな いが, かつては炭層が露出していた. また, 炭鉱の坑口跡が 露頭の南端にある.

\section{Stop 4 “大賀の押し被せ” 説明板と石灰岩（高梁市川上町 大賀；第 3,4図)}

[地形図] $1: 25,000$ 「地頭」

[位置] $34^{\circ} 43^{\prime} 22^{\prime \prime} \mathrm{N}, 133^{\circ} 27^{\prime} 36^{\prime \prime} \mathrm{E}$

[解説］Stop 3 から領家川を上流に遡って大賀地区に至ると， 左右両岸から山腹が迫ってくる.ここでは領家川左岸の護岸 部に「大賀の押し被せ（昭和12年 6 月 15 日 文部省指定天然 記念物)」と書かれた説明板がある。いうまでもなく, 1920 年代にトリアス系の上をペルム系が低角の断層で載るナップ 構造“大賀デッケ”（小澤，1924; Ozawa, 1925）が指摘され た地点である.

説明板にはトリアス系成羽層群の上にペルム系が低角の断 層を境に覆うような地質断面図が描かれている. 説明板近く の左岸道路沿い急崖には灰白色の石灰岩が広く現れており, また，すぐ下流方での砂岩の露出をみると，大局的にはこの 地点が成羽層群の砂岩と石灰岩体の境界近くであることが理 解できる.さらに, 河床には砂岩と石灰岩が点在することか ら, 分布の境界は河川を横断するように延びていると推定で きる．ただし，現在の露頭状況では両者の関係は不明である し，図示されているような構造が直接見えるわけではない. したがって, 説明板が示す地質構造などは一般の人々には理 解できるものではない.

この付近の成羽層群と石灰岩体との関係に関してはその後 も多く調査がなされ, 低角の断層説だけでなく, 不整合関係 
(a)
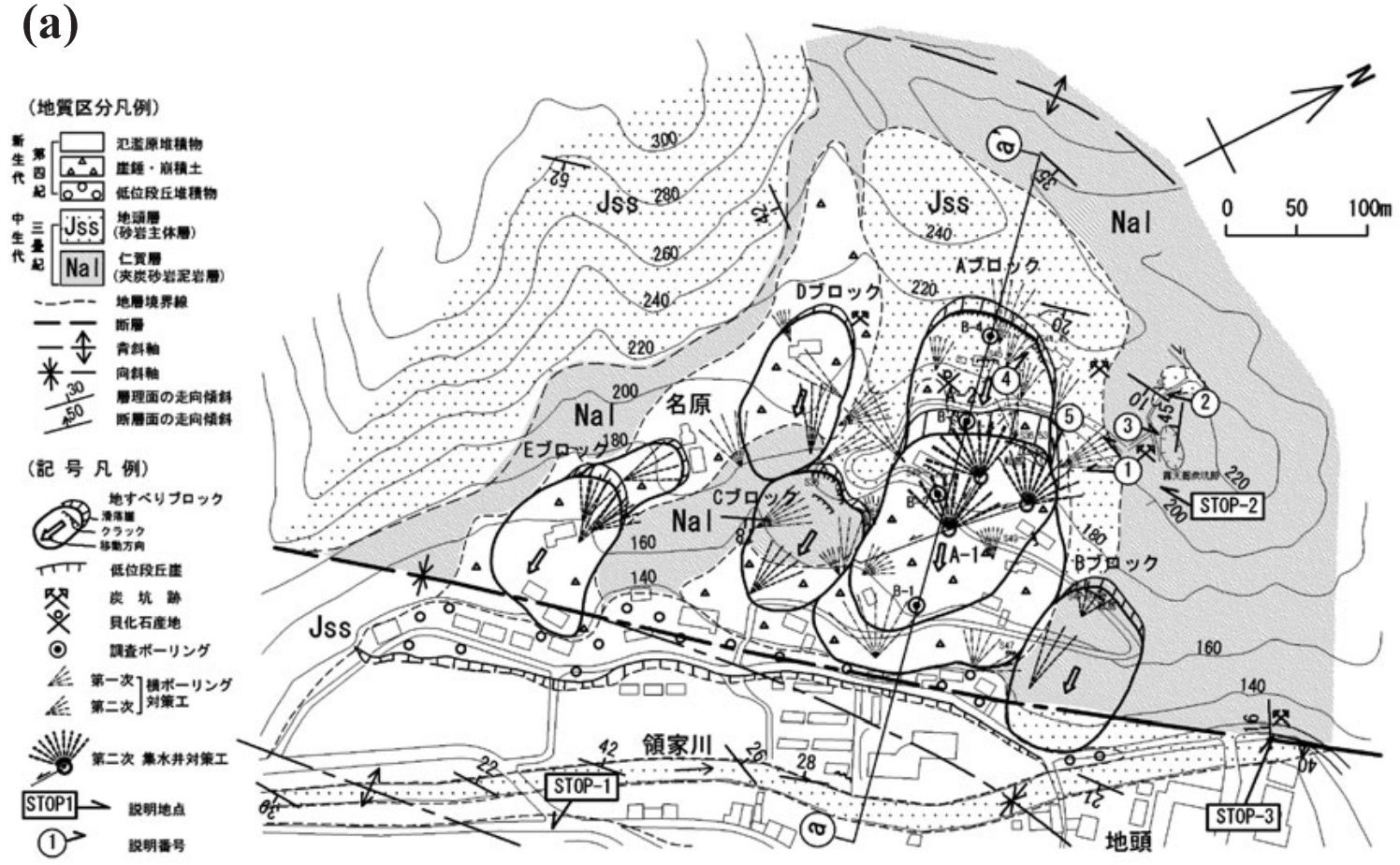

(b)

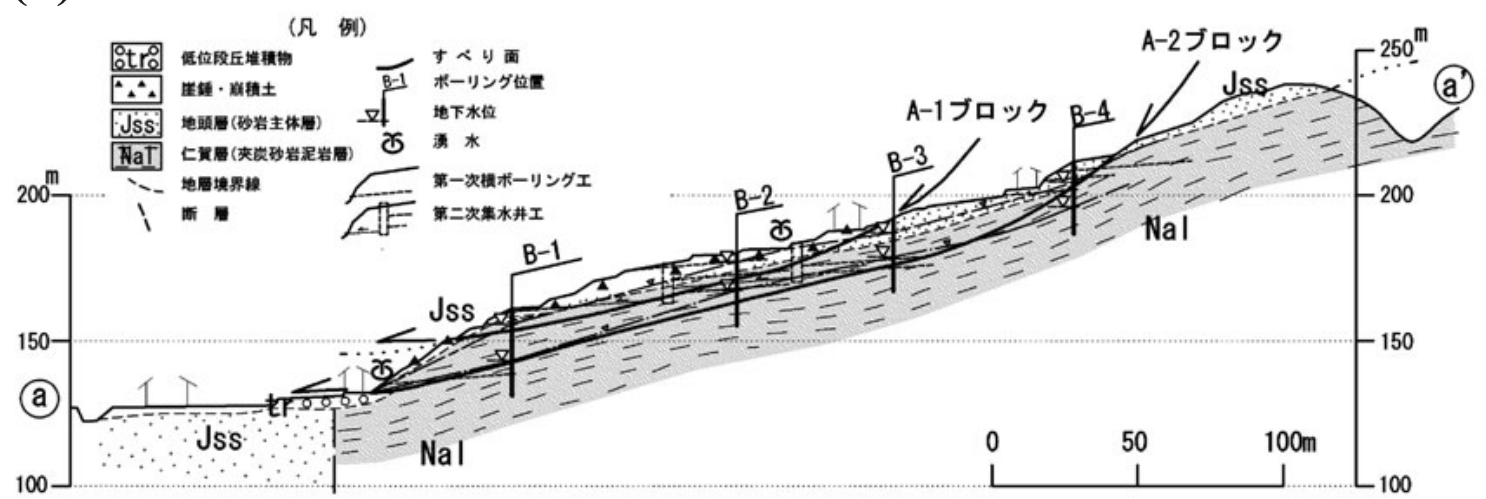

(c)

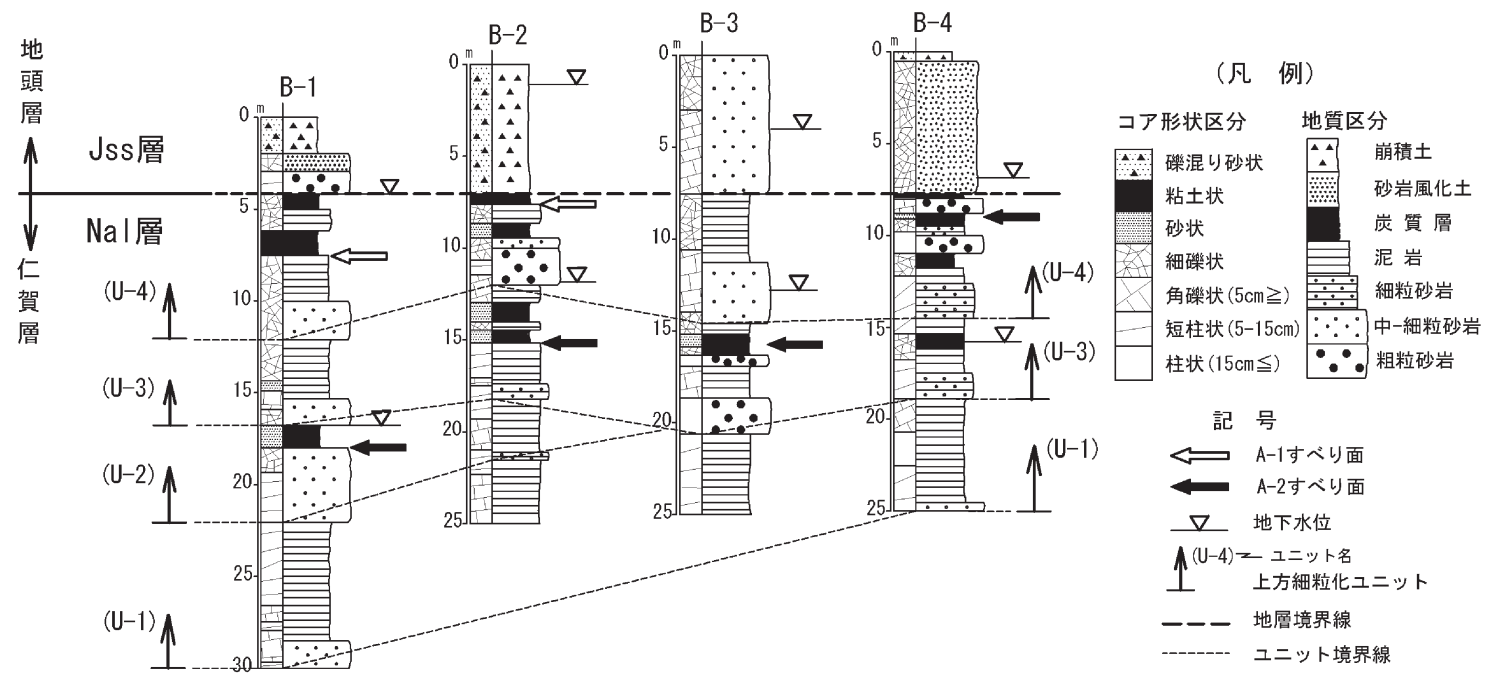

第 2 図 名原地すべり地区の地形と地質構成（田中ほか，2006)。(a) 地すべりブロックの区分および対策工． (1)～(5)はStop 2での観察箇所.

(b) Aブロックの地形・地質縦断面図 (a-a'断面)。 (c) ボーリング・コアに現れた炭層とそれに沿ったすべり面. U1〜U4は上方細粒化のユニット. 
も含めて様々な解釈がなされてきた（沖村・長谷，1973；大 藤，1985など). 第 3 図にこれまでの代表的な解釈を示す. 当地域全体としては, 石灰岩は成羽層群の下位にあり, 両者 は基本的に不整合関係と考えるのが妥当であろう。しかし， 石灰岩の一部は二次的な堆積物である可能性もある.

第 4 図(a)はStop 4,5を含めた地域の岩相分布ルートマップ である（横田ほか, 1998)。この地域には砂岩や砂岩・頁岩 （泥岩）互層, 石灰岩の他に塩基性火山岩類が点在している. 砂岩・頁岩互層はほぼトリアス系の成羽層群である. 砂岩ま たは砂岩優勢層にはペルム紀のものとトリアス紀のものが含 まれるが, 図ではそれらを含め, 地質時代を明記していな い. 山腹斜面に点在しているものには地すべり移動などによ る 2 次的な堆積物の含まれている可能性があるためである.

\section{Stop 5 大賀西方の岩相分布（石灰岩と塩基性火山岩類） （高梁市川上町松原；第 4, 5 図）}

[地形図] $1: 25,000\lceil$ 地頭」

[位 置] $34^{\circ} 43^{\prime} 15^{\prime \prime} \mathrm{N}, 133^{\circ} 27^{\prime} 26^{\prime \prime} \mathrm{E}$

[解 説］Stop 4 から領家川左岸の道路に沿って約 $250 \mathrm{~m}$ 上流 にいくと, 道路沿いに塩基性火山岩類が広く露出しており, この地点をStop 5 とする. 塩基性火山岩類は, 風化 - 変質に よって緑色を帯びたものから赤褐色を帯びたものなどが見ら れる. Stop 5からStop 4の方向（東側）をみると, 領家川を挟 んで左岸側 (北側) の最上山と右岸側 (南側) の南天山が遠 望される.いずれも頂部は石灰岩であり, 当地域の高標高部 には石灰岩が広く分布していることが分かる. 火山岩類の分 布は断片的ではあるが，大局的には石灰岩体の下位に分布し ている.

第 4 図(b)は第 4 図(a)の岩相分布に基づいて作成したStop 5 西方約 $400 \mathrm{~m}$ 付近を通る南北方向の地質断面図である.ここ では基本的にはペルム系の砂岩優勢層を成羽層群の砂岩・頁 岩互層が覆うが，その上にさらに石灰岩と塩基性火山岩類が 載っていることになる.ただし, 詳細な地質構造の把握には 岩相分布だけでなく, 地すべり移動による表層構造も含めて 検討していく必要がある.

当地区の南方では，1994年前後から山稜部を横切るかたち で広域農道が建設され, 掘削面に多く露岩が現れた。最大は 農道のカーブに沿った掘削法面で, 砂岩・頁岩の上位に薄い 凝灰岩とともに火山岩類が広く現れた（第 4 図(a)のLoc.C).
ここでの岩相分布の平面図を第 5 図(a)に示す. 本掘削法面に 関しては，藤本ほか (1994) や鈴木・Asiedu (1995)でも記載 されているが，第 5 図(a)は掘削が最大になった時点（長さ約 $70 \mathrm{~m}$, 法高約 $19 \mathrm{~m} ）$ のものである. 掘削面はその後モルタル が吹きつけられ, 全く見られなくなったことから, 現地では パネルにて紹介したい.

以下は横田ほか（1998）の記載による．第 5 図(a)に示すよ うに, 法面の下半分には主に砂岩と頁岩 (泥岩) が, 上半分 には火山岩類などが現れ, 後者は風化・変質による褐色化が 著しい. 最下段法面に広く現れる砂岩は, 粗粒〜中粒で, 塊 状または成層構造の砂岩である。これは不規則に泥岩を挟ん でいる．層理面は大局的にはいずれも西側へ緩傾斜している が，走向・傾斜の変化が大きい（横田ほか，1998）。中央部 ではN30〜 40 Eで北西に緩く傾斜しているが，東にいくと 水平ないし緩く南東側に傾斜しており, 結果として法面の東 端から約 $30 \mathrm{~m}$ 付近に軸をもつ小規模な背斜構造が推定された. 砂岩層の上位には層厚 $4 \sim 5 \mathrm{~m}$ の黒色炭質頁岩が存在する. これは剥離性を有し, 破砕されて軟質化し, 下位の砂岩との 境界は凹凸をなす。この炭質頁岩層はNE-SWの走向で北西 に緩く傾斜しており，下位の砂岩層と調和的である。頁岩優 勢部の上位には褐色を呈する軟質層が存在し，最大層厚約 1 $\mathrm{m}$ の安山岩質凝灰岩である。この東端では消滅している。こ れらの上位には灰褐色〜赤褐色, 一部緑褐色を呈する火山岩 類が存在し，安山岩質の溶岩〜灭砕岩と考えられた。

なお，石灰岩は本掘削面の南側などに広く分布している が，分布からは火山岩類の上位に位置することになる．本掘 削面を横断する地質断面図を描くと第 5 図(b)のようになる. 藤本ほか（1994）は砂岩・頁岩を成羽層群，軟質凝灰岩層か ら上位をペルム系と考え, 低角断層と解釈した. 上記の産状 からこの部分に沿ってなんらかの移動があったものと推定さ れるが，どのようなものか，時期を含めて明らかではない.

\section{Stop 6 山砂利層の露頭と吉備高原（高梁市川上町仁賀 ; 第 6図)}

[地形図] $1: 25,000$ 「地頭」

[位 置] $34^{\circ} 42^{\prime} 42^{\prime \prime} \mathrm{N}, 133^{\circ} 27^{\prime} 30^{\prime \prime} \mathrm{E}$

[解説］Stop 6は広域農道を南東方向に進んだ位置であり， 標高350〜400mのなだらかな山頂平坦面が連続している。フ ルーツパークとなっているが, その南西端には切土後約 10 年 (a)

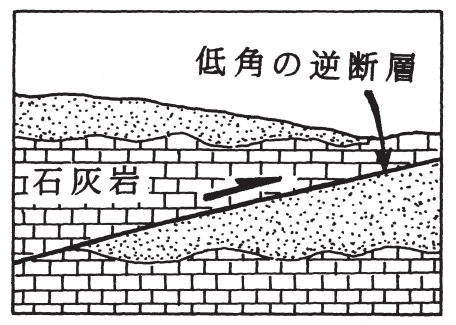

(b)

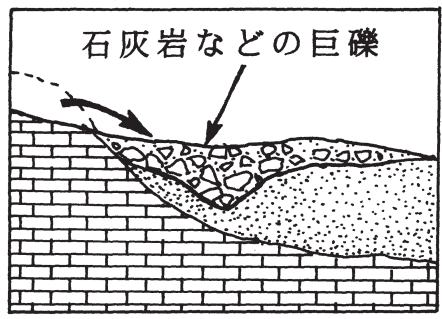

(c)

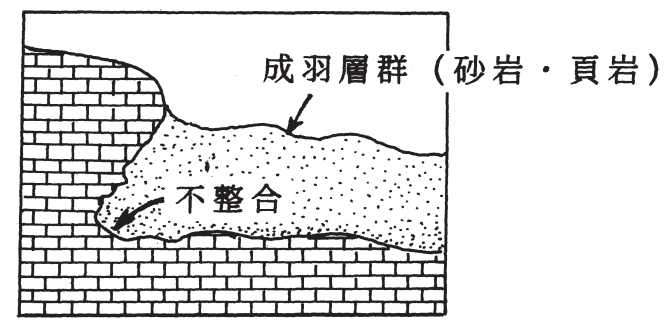

第3図「大賀の押し被せ」に対するいくつかの地質構造解釈例（横田ほか，1998)。(a) 低角逆断層によるナップ (デッケ)。(b)石灰岩ブロ ックの 2 次的堆積物との不整合面. (c) 起伏に富んだ不整合面. 


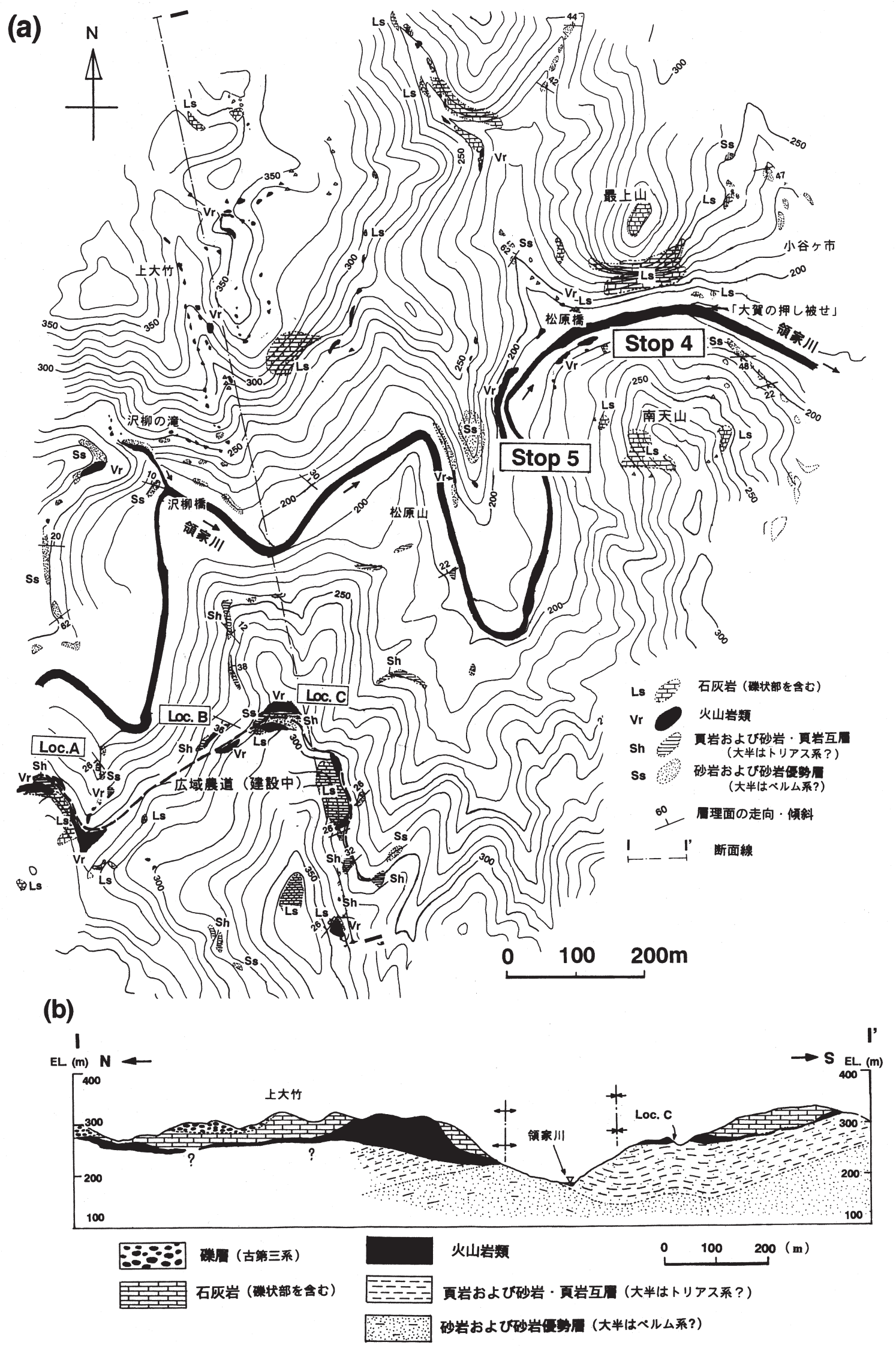

第4図 大賀地域に打ける石灰岩，塩基性火山岩類（火砕岩相を含む緑色岩類）砂岩優勢層，砂岩・頁岩互層などの分布（横田ほか，1998）. (a) 地質ルートマップ. Loc.Cは第 5 図の位置. (b) 領家川を横断するN-S方向の地質断面図. 

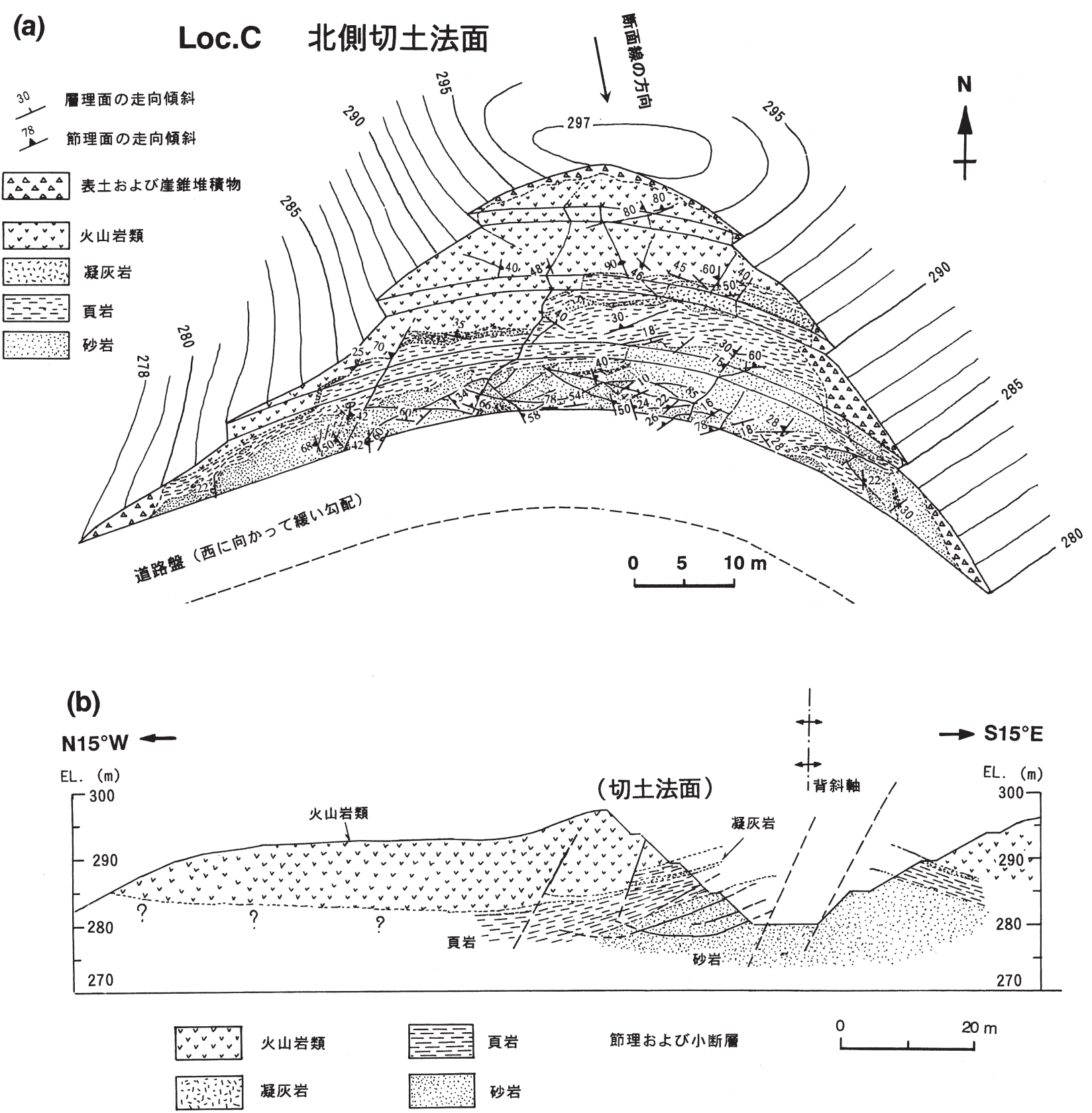

第5図 広域農道（Loc.C）の大規模な切土法面の平面図と地質断面図（横田ほか, 1998). (a)切土法面の平面図（第 4 図のLoc.C). (b)切土 法面を横断する地質断面図 (砂岩・頁岩の最大傾斜方向).

経過した北向き法面があり，河川成の山砂利層が露出してい る. 山砂利層は礫支持礫岩を主体として薄い砂岩レンズをは さんでいる，礫には比較的新鮮なものもあるが，風化が進み "くさり礫"となっているものも多い.しばしばインブリケー ションが認められ，ここでは扁平な礫の表面が北東に緩傾斜 していることから，南西方向への古流向が推定される．山砂 利層が示す古流路は，第 6 図に示すように大局的には南流し ているが，見学地点は流路が北東から西へと曲流する部分に あたる，流路底面は標高 $350 \mathrm{~m}$ 付近であり，堆積層厚は約 $50 \mathrm{~m}$ 以上である．後で観察するStop 9はこの流路の北東約 $500 \mathrm{~m}$ 上 流部に位置しており，流路底の不整合面と下位の成羽層群の 風化状況が観察できる。
こうした山砂利層は吉備高原上の広範囲に点在し, 大局的 には帯状に分布している。これらの山砂利層はかつては漠然 と更新統とされてきたが，最近多くの地点でフィッショント ラック年代によって始新世〜漸新世の值が得られ，基本的に は古第三系と考えられるようになってきた（鈴木ほか， 2003 ; 田中ほか，2003，Tanaka and Suzuki，2004など).山砂 利層は一般に層厚約 $100 \mathrm{~m}$ ら薄く，削剥されやすい層相で あるが，削剥を免れて高原上に広範囲に残存していることな どから, 当地域では古第三紀以降, 構造運動の少ない環境が 長く継続していたと考えられている（田中ほか，2003）。こ のため，高原上は風化による地質劣化が進みやすく，これも 当地域における地すべり多発のひとつの要因となっている可 


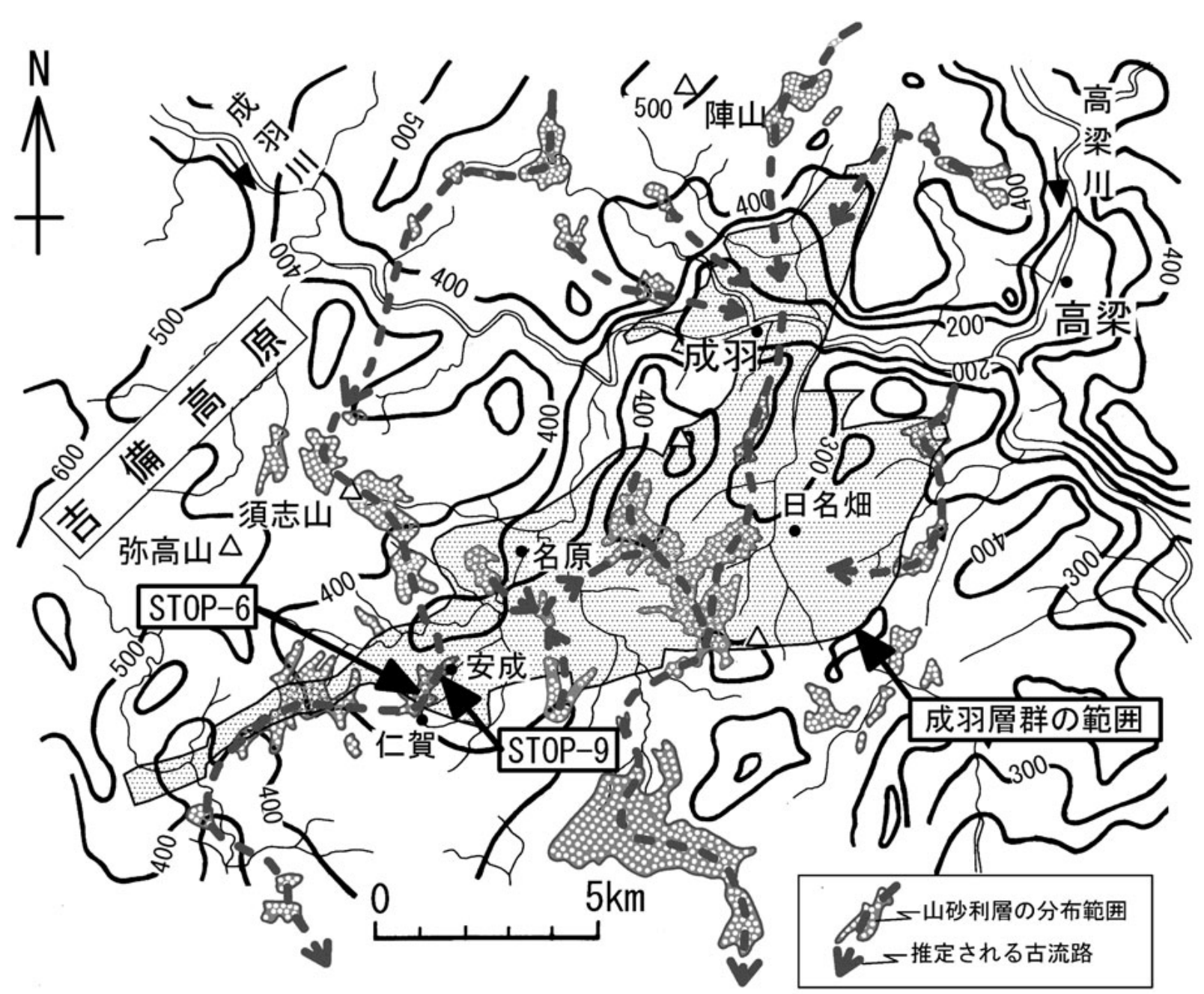

第6図 成羽層群分布域における山砂利層の分布と流路（田中，2007に基づく）.

能性がある。

Stop 7 向斜構造に規制された地すべりの露頭（高梁市川上 町安成；第 7,8 図)

[地形図] $1: 25,000\lceil$ 地頭」

[位 置] $34^{\circ} 42^{\prime} 36^{\prime \prime} \mathrm{N}, 133^{\circ} 27^{\prime} 54^{\prime \prime} \mathrm{E}$

[解 説] 安成地区には第7図に示すように，5つの地すべ りブロックが認められ，それらをLs-1〜Ls-5とした，当地区 全体の地すべりについてはStop 8で説明することとし，ここ ではLs-5ブロックのみを見学する.

Ls-5ブロックの地すべり地形はやや不明瞭であるが，地形 的には外側と内側の 2 つの地すべりブロックが推定される (第 7 図). 外側のブロックに関しては, 標高 $310 \mathrm{~m}$ 付近に比 高約 $5 \mathrm{~m}$ の滑落崖があり, 頭部の緩斜面は等高線でみると川 側へ張り出している. 側部は溝状の沢で区切られ，とくに北 側の沢は直線的で明瞭である.末端部に相当する河床から約 $15 \mathrm{~m}$ 高い標高 $275 \mathrm{~m}$ 前後では, 遷急線を伴い等高線は緩く川側 へ突出している。一方，内側のブロックに関しては，標高 $300 \mathrm{~m}$ 前後に低い滑落崖を伴った狭い頭部緩斜面が認められ る。この末端部は道路盛土のために確認できないが，標高 $290 \mathrm{~m}$ 前後の斜面中腹にあると推定される.
Ls-5ブロックの中央を約 5 年前に拡幅切土された道路が 通過し, 法面は全面露頭となっている.ここでは地すべりブ ロックの内部構造が観察できる(第 8 図).

当法面の地質構造と地すべりとの関係を第 8 図(a)に基づい て説明する. 図中に地点番号(1)〜 (7)を付している. 法面は層 理面の走向とほぼ直交している，炭層をはさむ砂岩・泥岩互 層の層理面は，南端で約 $60^{\circ}$ 北傾斜（第8図中の地点(5)）を 示すが，北にいくにつれて徐々に緩傾斜（地点(3)）になる. 地点(2)では緩く小褶曲するが, 地点(1)付近から南傾斜に変化 する．地点(1)付近には向斜軸が認められる．層理面のステレ オ投影解析から，この向斜軸は $\mathrm{N} 85^{\circ} \mathrm{W}$ 方向で西方に約 $5^{\circ}$ でプ ランジしている.

一方, 地すべり地形と対応させると, 強く破砕した炭層の 層理面は 2 つすべり面と考えられる。法面には開口亀裂を 伴う緩みが認められるため, 第 8 図(b)に緩みの強弱を定性的 に示した。これによれば，2つのすべり面付近では緩みが強 く, すべり面-1の上部はすべり面-2の上部より緩んでいる.

すべり面付近を詳しくみると, 地点(2)付近のすべり面-1で はすべり面は厚さ約 $50 \mathrm{~cm}$ の塊状砂岩層の上面に沿っており, 鏡肌と条線を伴う褐色〜灰色の薄い粘土が観察できる.この 直上には軟質化した厚さ $10 \sim 50 \mathrm{~cm}$ の炭層が存在する.ここ 
では細粒化した薄く葉片状を呈する破砕片がすべり面に沿っ て配列している．すべり面直下では，塊状砂岩層が $10 〜 30 \mathrm{~cm}$ 間隔の節理面に沿って開口・破断し，破砕した炭層がその開 口部を埋めるように上から下へ侵入している。

地点(6)付近のすべり面-2は, 著しく破砕され，砂〜粘土状 に脆弱化した炭層を含む厚さ約 $4 \mathrm{~m} の$ 泥岩層の最下端とした。 ここには多量の湧水が認められ, 下位の砂岩層との境界面に
は弱い条線を伴う厚さ約 $1 \mathrm{~cm}$ の青灰色の軟質な粘土が挟ま れる。一方，すべり面-2より下盤の地点(7)では地すべり移動 の影響はなく, クラックは密着している。また, 地点(4)では 北側に凸部を向けた屈曲構造が認められる。これに関して は, 両翼が平面的で折れ曲がるような形態であること, 軸面 が水平に近いこと, 大きく見ると斜面外側に向かって凸型を なすことなどの特徴から, 横田ほか（2001）はさらに古い地

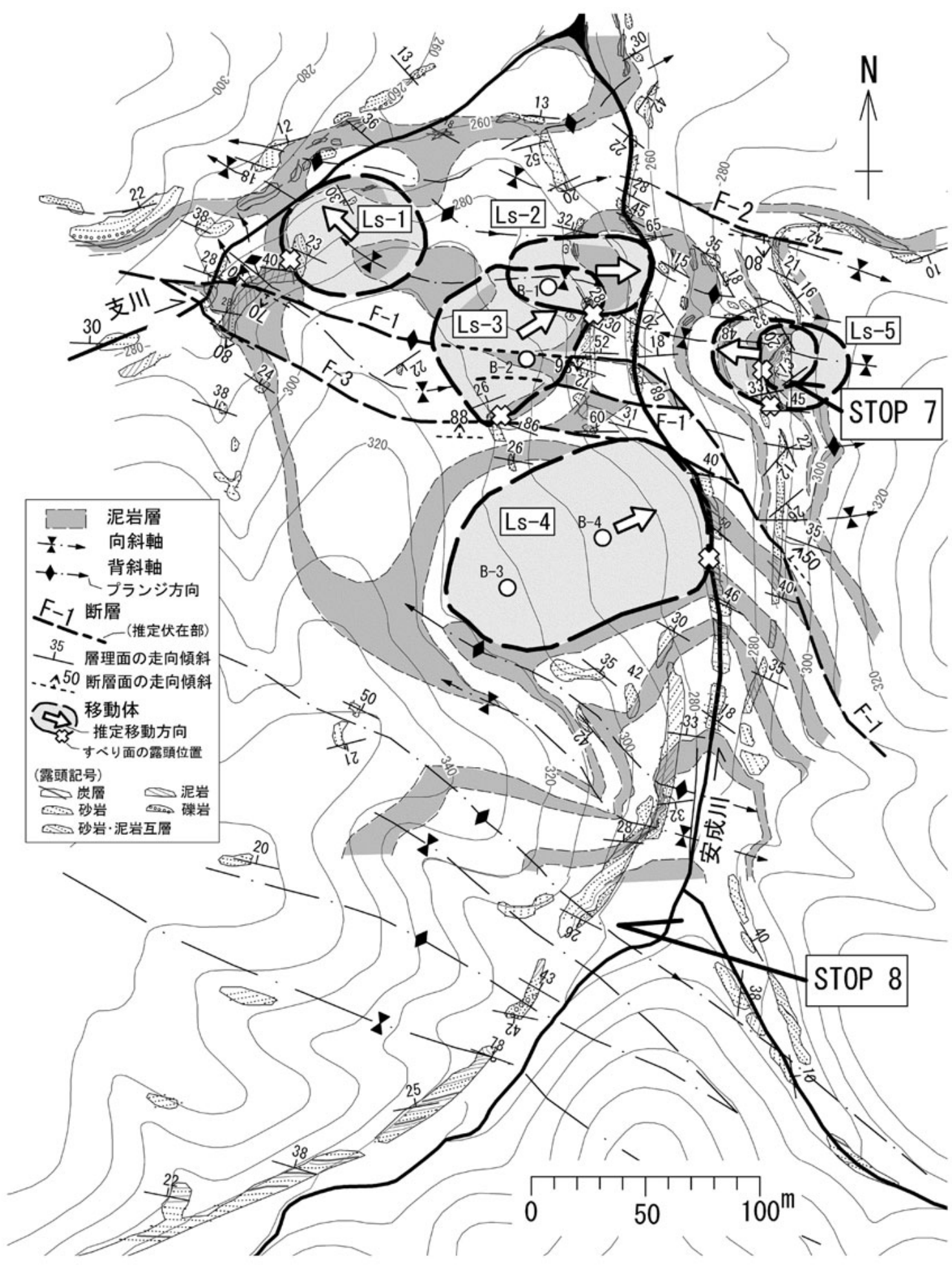

第7図 安成地区の地質ルートマップと見学箇所（Stop 7,8）（田中ほか，2007に基づく）. 


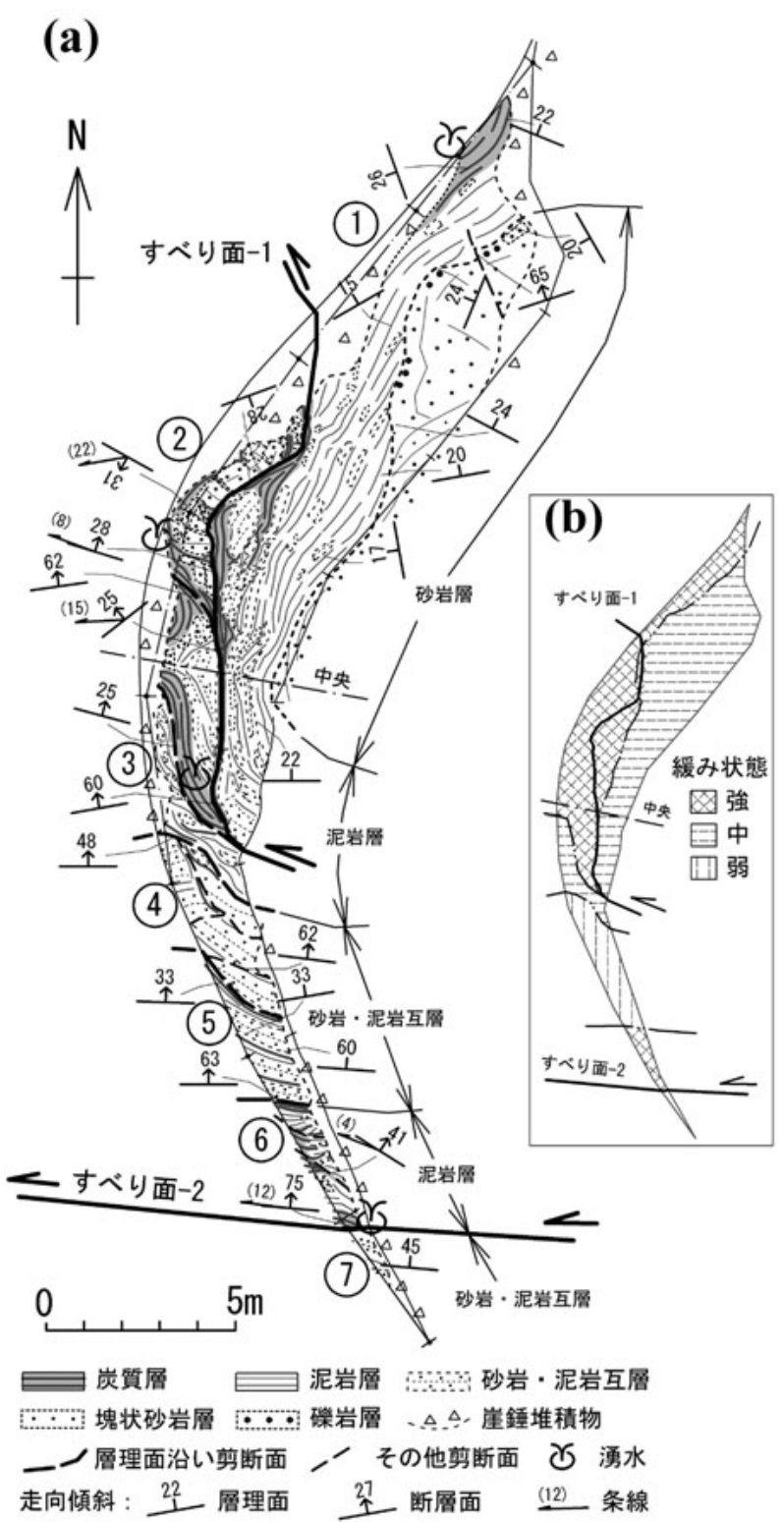

第 8 図 安成川右岸Stop 7における地すべりブロックLs-5を中心 とした露頭スケッチ（田中ほか，2007)。(a)切土法面の平面図. (b)切土法面の緩み状態区分図.

すべり移動の痕跡を示す地質構造の可能性があると指摘して いる.

以上のことから, Ls-5ブロックでは, すべり面が向斜構造 をなす脆弱な炭層部に形成され，その上盤の部分が向斜軸の プランジ方向へ移動して地すべりを形成したと推定される. このため, 移動体内部には地すべりによる局部的な剪断面と もとの向斜構造が残存しているものと考えられる.

Stop 8 安成地すべりと地質構造との関係および成羽層群地 すべりのタイプ（高梁市川上町安成；第 7, 9,10 図)

[地形図] $1: 25,000\lceil$ 地頭」

[位 置] $34^{\circ} 42^{\prime} 30^{\prime \prime} \mathrm{N}, 133^{\circ} 27^{\prime} 48^{\prime \prime} \mathrm{E}$

[解 説] 安成地区周辺の成羽層群では小褶曲構造がとくに
明瞭で，地層中には脆弱化した炭層が繰返し挟まれている。 地すべりは，こうした脆弱な炭層の層理面をすべり面として いると考えられている（田中ほか，2007）.Stop 8は安成地 すべりに隣接し，道路沿いの露頭状況が良好なため，成羽層 群の岩相と地質構造の特徵を概観するとともに，安成地区に おける地質構造と地すべりの関係を説明し，成羽層群地す心゙ りに多くみられる地すべりのタイプを総括する。

第 7 図に安成地区周辺のルートマップと地質構造，ならび にStop 8の位置を示す．主に砂岩と泥岩からなるが，詳細に みると，上位へ向かって磁岩層を含んだ砂岩層，厚さ10〜 $30 \mathrm{~cm}$ の砂岩と泥岩の互層，および砂岩薄層と炭層を含む泥 岩層が累重し，最上部には炭層が頻繁に認められ，全体とし て厚さ10〜30mの上方細粒化ユニットを構成している．層理 面は，NW-SE〜WNW-ESE走向で北へ緩傾斜するものが多い が，傾斜方向は狭い範囲で頻繁に変化し，多数の小褶曲構造 が認められる．褶曲軸は地層の走向と調和してNW〜WNW 方向で，いずれも開いた褶曲構造である.

集落があるLs-2，3，4は昭和53年に地すべり防止区域に指 定された。ここでは，明治初年と昭和 $51 ， 55$ 年に地すべり変 動の記録がある．B-1〜4の 4 本のボーリング調査のうち，B2 では昭和55年にすべりによる変位が確認されている，対策 としては，排水ボーリング工による地下水排除が中心で，一 部では鋼管杭工も施工された（岡山県，1987）。その後は変 状の報告はなく，安定化している.

地すべりブロックと地質構造の関係（第 7 図）をみると, 5 つのブロックのうち，Ls-1，2，5は向斜構造に対応し，移 動方向はそれぞれの軸のプランジ方向と推定される．これに 対しLs-3，4は同斜構造に対応し，移動方向は層理面の傾斜 方向に近い。なお，すべり面はいずれのブロックも主に炭層 を含む泥岩層の層理面に沿うものと推定されている。このよ うに，当地区の 5 つの地すべりブロックには地質構造に依存 した「同斜構造型」と「向斜軸型」の 2 つのタプが認めら れる (第 9 図).

なお，成羽層群の地質構造と地すべり移動方向の関係は， 広い範囲の多数の地すべりを対象として統計的にも検討した (田中ほか，1999；田中ほか，2007）。第10図は，成羽層群仁 賀層分布域を対象とした122箇所の地すべり地において，地 形的に推定される地すべり移動方向とその近傍の層理面の傾 斜方向との斜交角度の度数分布を示したものである。これに よれば，成羽層群地すべりには受け盤型は少なく，典型的な 流れ盤型ないしは層理面の走向方向に移動する横盤型が多 い．流れ盤型の場合には，地質構造が素因となっていること は自明であるが，横盤型の場合には明確ではない。しかし， 前述した「向斜軸型」では層理面の走向方向が地すべりの移 動方向となることから，成羽層群には「向斜軸型」が多く存 在する可能性があるものと解釈できる（田中ほか，2007）.

このように，成羽層群では褶曲構造が形成されており，こ のうち斜面に対して流れ盤となる小規模な褶曲部で，炭層を すべり面とする地すべりが発生しやすいという特徵がある。 
Stop 9 山砂利層直下の風化した成羽層群（高梁市川上町安 成；第11図）

[地形図] $1: 25,000$ 「地頭」

[位 置] $34^{\circ} 42^{\prime} 48^{\prime \prime} \mathrm{N}, 133^{\circ} 27^{\prime} 42^{\prime \prime} \mathrm{E}$

［解 説］広域農道から東方に折れ，安成集落に降りていく 道路沿いには炭層を伴う成羽層群の砂岩・泥岩が連続的に露 出しているとともに，標高 $360 \mathrm{~m}$ 以上の高標高部には山砂利 層の大磦が分布している。 このため, 不整合面直下の強風化 した成羽層群の状況，とくに風化した炭層周辺での層理面方 向の頻繁な変化などをよく観察できる.

この区間の地質分布とスケッチを第11図に示す，道路法面 は最大高さ約 $3 \mathrm{~m}$ にすぎないが, 図には標高380〜 360m, 延 長約150mの区間のものを示している，砂岩が主体であるが, 泥岩とともに炭層も多数挟まれている。ここでは炭層を黒色 太線で示している，全体として向斜構造をなしているが，層 理面の走向・傾斜は狭い範囲内でも頻繁に変化している. 10
〜 30の低角を示す部分は局所的な崩壊や地すべり移動に伴 うものと推定される.これ以外に微小な屈曲なども認められ る。炭層はほとんど軟質化しており, それに沿った砂岩も多 くの場合，角礫化している.

\section{Stop 10 川上町郷土資料館（高梁市川上町地頭）}

[地形図] $1: 25,000$ 「地頭」

[位 置] $34^{\circ} 44^{\prime} 12^{\prime \prime} \mathrm{N}, 133^{\circ} 29^{\prime} 06^{\prime \prime} \mathrm{E}$

[解 説］旧川上町内にて古くから使用されてきた農具, 民 具に加え, 各種化石類が展示されている. 地学展示室が設け られており, 地質時代と地史の説明と鉱物, 岩石, 貝化石な どの展示がある. 旧川上町では一時期「地学」を通じて町興 しを企画されていたようでもあり，その活動がこうした資料 館の設置になった。ジオパークが議論される今日，こうした 地方の資料館をみて，地質学と社会との接点を考えたい.
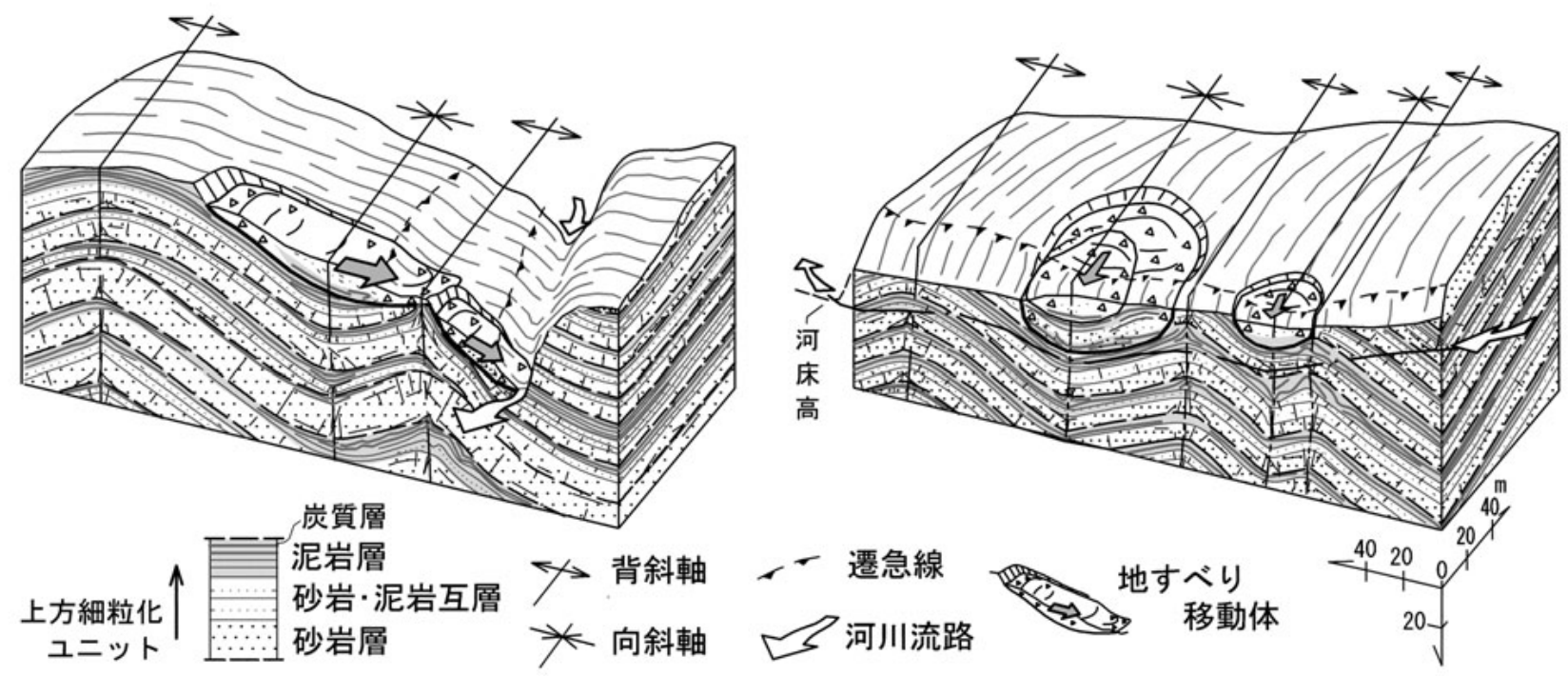

第9図 安成地区の地すべりで得られた“褶曲構造に規制された地すべり移動”の 2 つのタイプ. 左：同斜構造型，右：向斜軸型（田中ほ か, 2007).
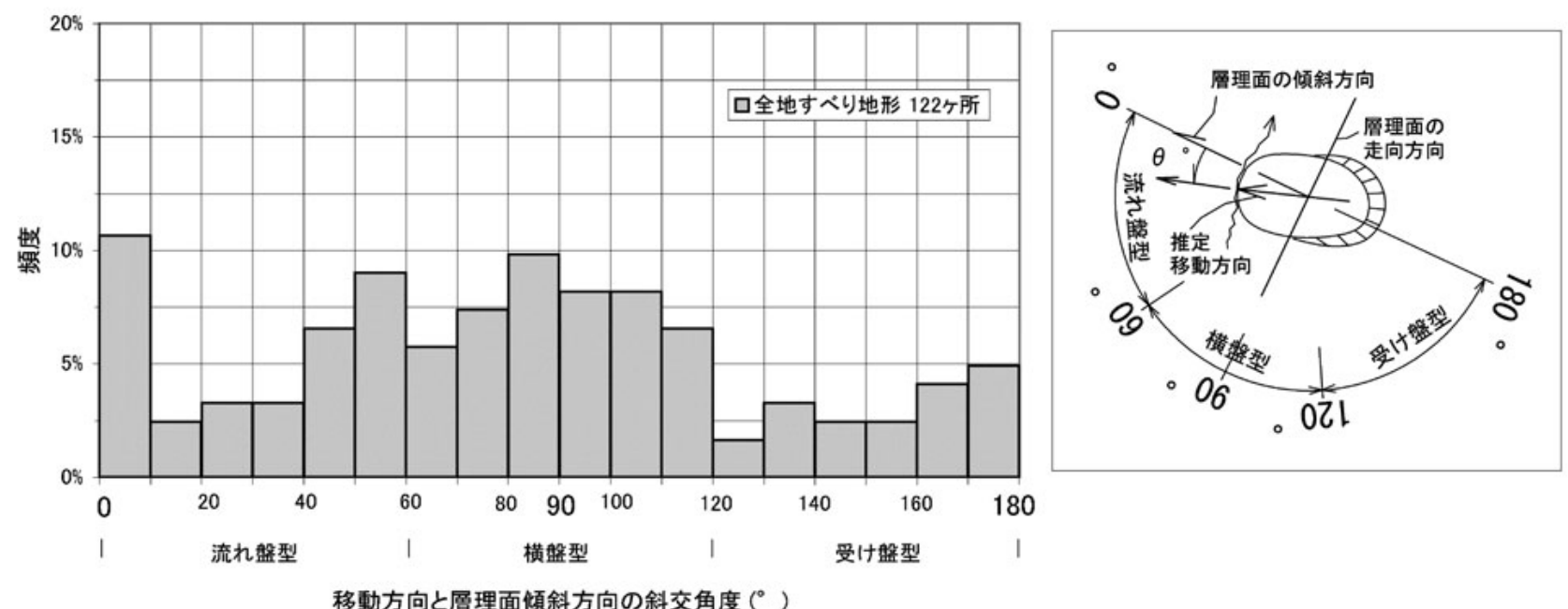

第10図 成羽層群地すべりにおける移動方向と層理面の交角の度数分布. 移動方向は地すべり地形から推定したもの（田中ほか，2007）. 


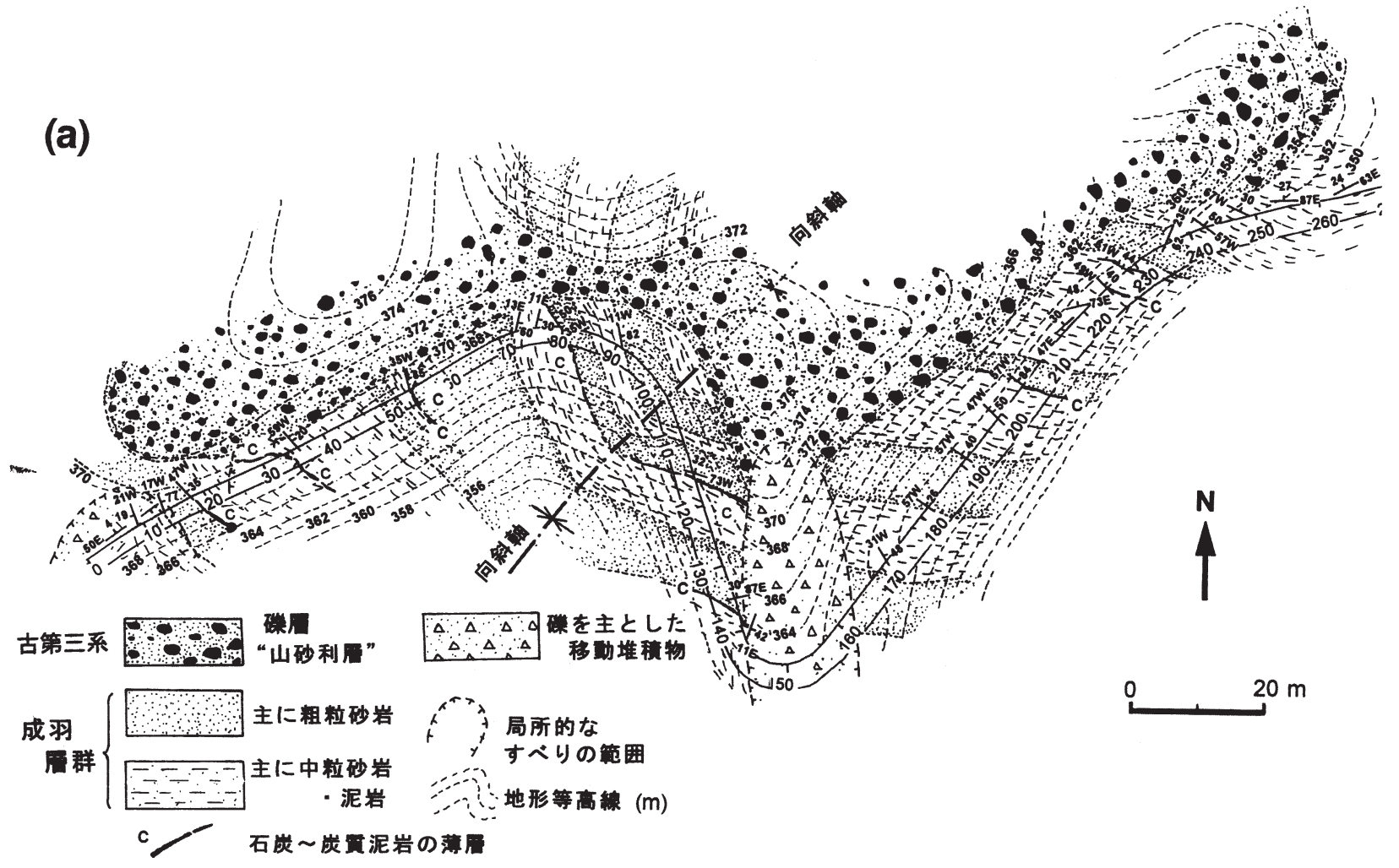

(b)
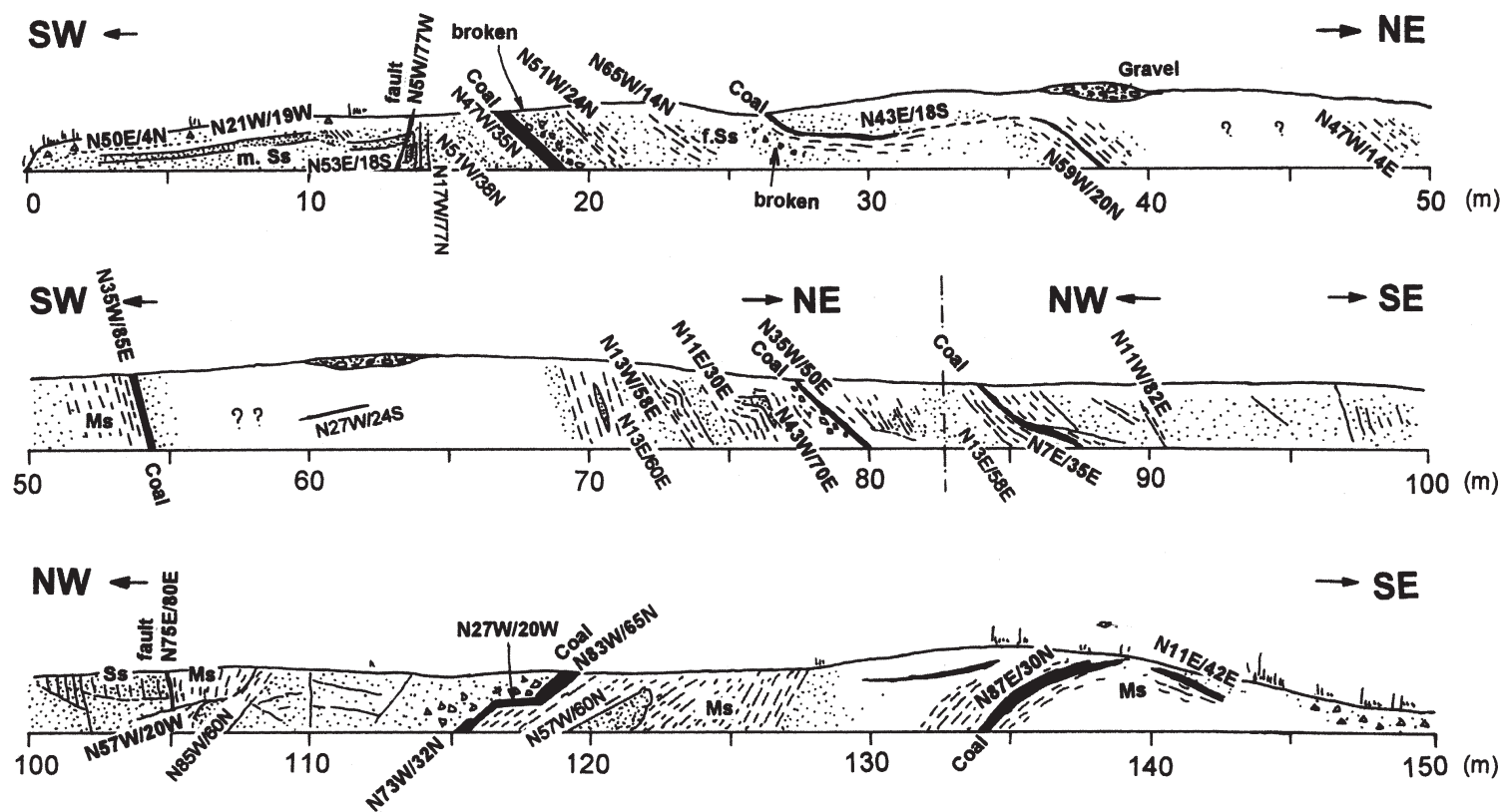

第11図 安成地区背後における稜線部の成羽層群の岩相と道路沿いの層理面方向の変化（横田ほか，2001）。(a) 道路沿いの地質分布. (b)道 路沿いに連続して現れた成羽層群の砂岩・泥岩と炭層の走向・傾斜の変化.

\section{謝 辞}

当見学コースの設定に際しては，岡山県備中県民局建設部 高梁地域事務所ならびに高梁市川上地域局地域振興課の皆様 には様々な便宜を図っていただいた。また，本見学案内原稿
に関して, 岡山大学・鈴木茂之先生, 鹿児島大学・井村隆介 先生には査読いただき，表現の不備などを指摘いただいた。 関係者の皆様方には記して謝意を表します。 


\section{文 献}

藤本 睦・於保幸正・平山恭之, 1994, 岡山県大賀南西部における 非変成古生層と上部三畳系成羽層群の間の衝上断層. 地質雑, $100,709-712$

宝谷 周・鈴木茂之 · 田中 元 · 山田玩哉, 1997, 三畳系成羽層群 の地質と地すべり. 岡山大学地球科学研究報告, 4,21-32.

井上 基・山田玩哉・田中 元・北川隆司，2001，岡山県の三畳紀 層に発達する野田地すべり地のすべり面の起源について. 応 用地質， $42 ， 88-100$.

河合正虎，1951，岡山県成羽町附近の上部三畳系．地質調查所報 告，特別号，57-72.

川上町岩石植物調查会，1970，川上町地質関係文化財とその解説， （III）大賀デッケン．川上の自然, 83-85.

小林貞一 - 堀越義一 ・昭和11年度東大地質学科中期生一同，1937, 吉備高原の地史に就いて。地質雑, 44, 797-821.

松浦浩久 - 栗本史雄 - 吉田史郎 - 斉藤文紀 - 牧本 博 - 利光誠一 巌谷敏光・駒澤正夫・広島俊男，2002，20万分の1地質図幅 「岡山及び丸亀」. 産業技術総合研究所.

大石三郎，1931，備中成羽地方上部三畳紀層に就いて。地質雑, 38, $1-8$.

岡本広文・田中元，1990，岡山県における地すべりの地質特性一 特に中生代成羽層群に頻発する地すべりの特徵一. 第29回地 すべり学会研究発表講演集, 84-87.

岡山県，1987，地すべり防止区域台帳，安成（追加）地区，地す ベり防止区域設備箇所調査報告書. 岡山県, 17-21.

岡山県，2000，地すべり防止工事基本計画書，No.5名原地区．岡 山県, 228p.

沖村雄二 ・長谷 晃, 1973, 岡山県成羽町北西部の “大賀衝上”. 梅垣嘉治先生退官記念文集，113-120.

大藤 茂, 1985 , 岡山県大賀地域の非変成古生層と上部三畳系成羽 層群の間の不整合の発見. 地質雑, 91, 779-786.

小澤儀明，1924，中生代末の大押し被せ。地質雑，31,318-319.

Ozawa, Y. ,1925, The Post-Paleozoic and late-Mesozoic earth-movements in the Inner Zone of Japan. Jour. Fac.Sci., Imp. Univ. Tokyo, ser.2, $1,91-104$.

鈴木舜一・小田幸人，1995，西南日本内帯夾炭三畳系のビトリナ
イト反射異方性と熱構造. 地質雑，101，605-614.

鈴木茂之 - 小坂丈与 - 光野千春, 昭和 61 年度岡山大学地学科進級 論文履修生一同，1990，岡山県川上郡周辺の古生界および三 畳系にみられる裮曲の構造解析．地質雑，96,371-377.

鈴木茂之・Asiedu,D.K., 1995，岡山県成羽地域の中・古生界. 日 本地質学会第102年学術大会（広島）見学旅行案内書，89-95. 鈴木茂之・檀原 徹 - 田中 元, 2003, 吉備高原に分布する第三系 のフィッション・トラック年代. 地学雑, $112 ， 35-49$.

田中 元，1999，成羽層群の地すべり。日本応用地質学会編，「斜 面地質学一その研究動向と今後の展望 -」. 日本応用地質学 会, 258-262.

田中元, 2007, 三睍系成羽層群分布地域に発生する地すべりの地 質素因一小褶曲構造と “破砕炭質層”に規制される地すべ り一。岡山大学自然科学研究科博士論文, 197p.

Tanaka. H. and Suzuki. S., 2004, The Paleogene gravelly valley-fill deposits in the Kibi plateau area, Okayama Prefecture, southwest Japan. Proc. 32nd Intern. Geol. Congr., General Symposia, G21-02, 223-224.

田中 元 · 鈴木茂之 · 宝谷 周 - 山本裕雄 - 壇原 徹, 2003, 吉備高 原周辺の古第三系に関する最近の知見とその古地理学的意義. 岡山大学地球科学研究報告, no.10, 15-22.

田中 元・山田环哉・鈴木茂之, 2006, 成羽層群地すべりの特徵一 “破砕炭質層”とすべり面の形成・発達との関係一。応用地 質, $47,272-281$

田中 元 · 山田玩哉・横田修一郎・鈴木茂之, 2007, 岡山県, 成羽 層群の小褶曲構造に規制された地すべりとその内部構造. 応 用地質, 48, 232-240.

寺岡易司, 1959, 岡山県成羽町南域の中 - 古生層, 特に上部三畳 系成羽層群について。地質雑，65, 494-504.

徳永重元 - 高井保明 - 曽我部正敏 - 谷 正巳 - 植田芳郎 - 井上英 二・鈴木泰輔・尾上 亨, 1973 , 日本炭田図第 2 版，20万分の 1地質編集図. 地質調查所.

横田修一郎・松村聡明・島内 健，1998，岡山県川上町における 成羽層群とそれを覆う石灰岩体の構造関係. 島根大学地球資 源環境学研究報告, no. 17, 31-47.

横田修一郎・杉山光正，2001，岡山県川上町における成羽層群の 微小構造と地すべり移動の痕跡. 島根大学地球資源環境学研 究報告, no. 20,143-152 